\title{
A SURVEY OF MICROEARTHQUAKE ACTIVITY ALONG THE SAN ANDREAS FAULT FROM CARRIZO PLAINS TO LAKE HUGHES
}

\author{
By R. Carlson, H. Kanamori, and K. McNally
}

\section{ABSTRACT}

An array of moveable seismographic trailers was deployed at three sites along the northern section of the "Big Bend" in the San Andreas fault in southern California. The three sites monitored were the Carrizo Plains, Frazier Park, and Lake Hughes areas. Effective observation times at each site ranged from 38 to 69 days. The microearthquake activity rates observed were 0.3 events/day, 3.0 events/day, and 1.9 events/day, respectively, based on the number of located events plus the number of unlocated events with $S-P \leqq 3.0$ sec. The majority of the activity does not appear to be directly associated with the San Andreas fault. A comparison of the activity rates observed in this study with the results of a survey conducted in the same areas by Brune and Allen (1967), indicates more than an order of magnitude increase in activity rate in the Lake Hughes area and nearly the same levels of activity at the Carrizo Plains and Frazier Park sites.

\section{INTRODUCTION}

The purpose of this study is to monitor the seismicity along the "Big Bend" in the San Andreas fault from the Carrizo Plains to Lake Hughes at magnitude thresholds $M_{L} \leqq 3.0$. Since 1932, the San Andreas has been relatively quiescent in this region at magnitude thresholds $M_{L} \geqq 4.0$ (Figure 1; Hileman et al., 1973). Low levels of microearthquake activity were also observed in the study areas during a survey conducted by Brune and Allen (1967). In light of the fact that this segment of the San Andreas ruptured during the great Ft. Tejon earthquake of 1857 and has ruptured at least nine times in the last 1500 years (Sieh, 1978), it is important to document current low-magnitude seismic activity with an eye toward a more complete understanding of seismic processes in this critical region.

\section{DATA}

The instrumentation used in conducting this microearthquake study consisted of an array of five to seven moveable seismograph trailers which employ Ranger-type seismometers and a $70-\mathrm{mm}$ film recording system operating at a recording rate of $1.5 \mathrm{~mm} / \mathrm{sec}$. A detailed description of the trailer system is presented by Lehner and Press (1966). The response curve for the instruments used in this study peaks at a period of $0.054 \mathrm{sec}(18.5 \mathrm{~Hz})$ for all gain settings. Instrument gain was set to optimize the signal-to-noise ratio at each site and ranged from peak magnification of $4.5 \times$ $10^{7}$ at the best sites to $5.6 \times 10^{6}$ at the most noisy sites. Station sites were chosen based on the criteria of desired areal coverage, lowest possible cultural and natural noise levels, and accessibility. The average station separation within each array was 10 to $15 \mathrm{~km}$.

All records were carefully screened to exclude known explosions and all seismic events with epicenters outside the array area. Records from permanent CaltechUSGS network stations in the vicinity of each site were used to augment the data set used in determining the hypocenters of the microearthquakes recorded by the trailer array. $P$-wave arrivals and, when readable, $S$-wave arrivals were read to \pm 0.1 
sec and used as input data into the earthquake hypocenter location program, HYPO71 (Lee and Lahr, 1975). Several sets of hypocenters were computed for each event using constrained and unconstrained focal depth and various initial focal depth estimates in order to find a "best" hypocenter. The crustal velocity structure assumed in computing the hypocenters was $5.5 \mathrm{~km} / \mathrm{sec}$ from the surface to $5.5 \mathrm{~km}$, $6.3 \mathrm{~km} / \mathrm{sec}$ from 5.5 to $16 \mathrm{~km}, 6.7 \mathrm{~km} / \mathrm{sec}$ from 16 to $32 \mathrm{~km}$, and $7.8 \mathrm{~km} / \mathrm{sec}$ below $32 \mathrm{~km}$. This velocity model is based on refraction surveys utilizing quarry blasts in southern California (Kanamori and Hadley, 1975). All hypocenters are graded in quality from "A" to "F" depending on the following criteria

A: $\quad \geqq 3$ stations, at least 2 with $S$ readings, both $P$ and $S$ residuals small. ( $P$ residual $\leqq 0.1 \mathrm{sec}, S$ residual $\leqq 0.15 \mathrm{sec}$ )

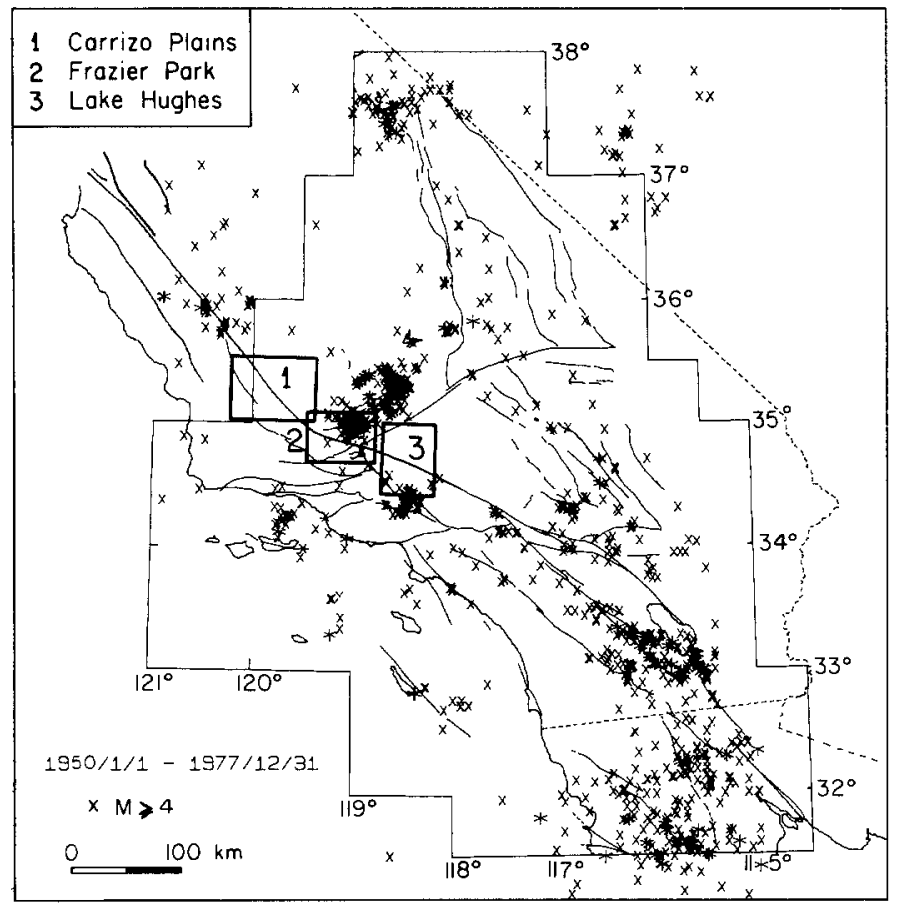

FIG. 1. Map of southern California showing the distribution of earthquake epicenters, $M_{L} \geqq 4.0$, that occurred between 1950 and 1977 . Boxed areas indicate the survey sites discussed in this paper.

B: $\quad \geqq 3$ stations, at least one with a $S$ reading or $\geqq 5$ stations with $P$ readings only, both $P$ and $S$ residuals small. ( $P$ residual $\leqq 0.1 \mathrm{sec}, S$ residual $\leqq$ $0.15 \mathrm{sec})$

C: $\quad \geqq 3$ stations, some mediocre $P$ readings, no reliable $S$ readings. $(0.1$ sec $\leqq P$ residual $\leqq 0.25 \mathrm{sec}$ )

D and F: Large residuals, very questionable location. ( $P$ residual $>0.25 \mathrm{sec}$ ).

The assigned quality rating for each event is designated on the epicenter maps for each of the three surveyed sites, using the convention outlined in the legend.

Magnitude estimates for each event were computed using an empirical magnitudecoda length relationship developed for use with standard USGS seismographic instrumentation. This empirically derived formula expresses $M_{L}$ as a function of coda length ( $T$ in seconds) and distance ( $\Delta$ in kilometers) from the station to the epicenter of the event (Lee et al., 1972) 


$$
M_{L}=-0.87+2 \log T+0.0035 \Delta \text {. }
$$

Strictly speaking, this formula cannot be applied to instrumentation with different response characteristics than the USGS instruments, but a comparison of $M_{L}$ computed using the above formula with $T$ measured from the trailer-recorded seismograms did not differ more than \pm 0.2 from magnitude values computed for the same event using records from the permanent network stations. Hence, the magnitudes computed for the trailer-recorded microearthquakes should constitute good first-order estimates of the "actual" $M_{L}$ values. The hypocentral data are tabulated in the Final Technical Reports of the U.S. Geological Survey Contracts 14-08-000115893 and 14-08-0001-16711.

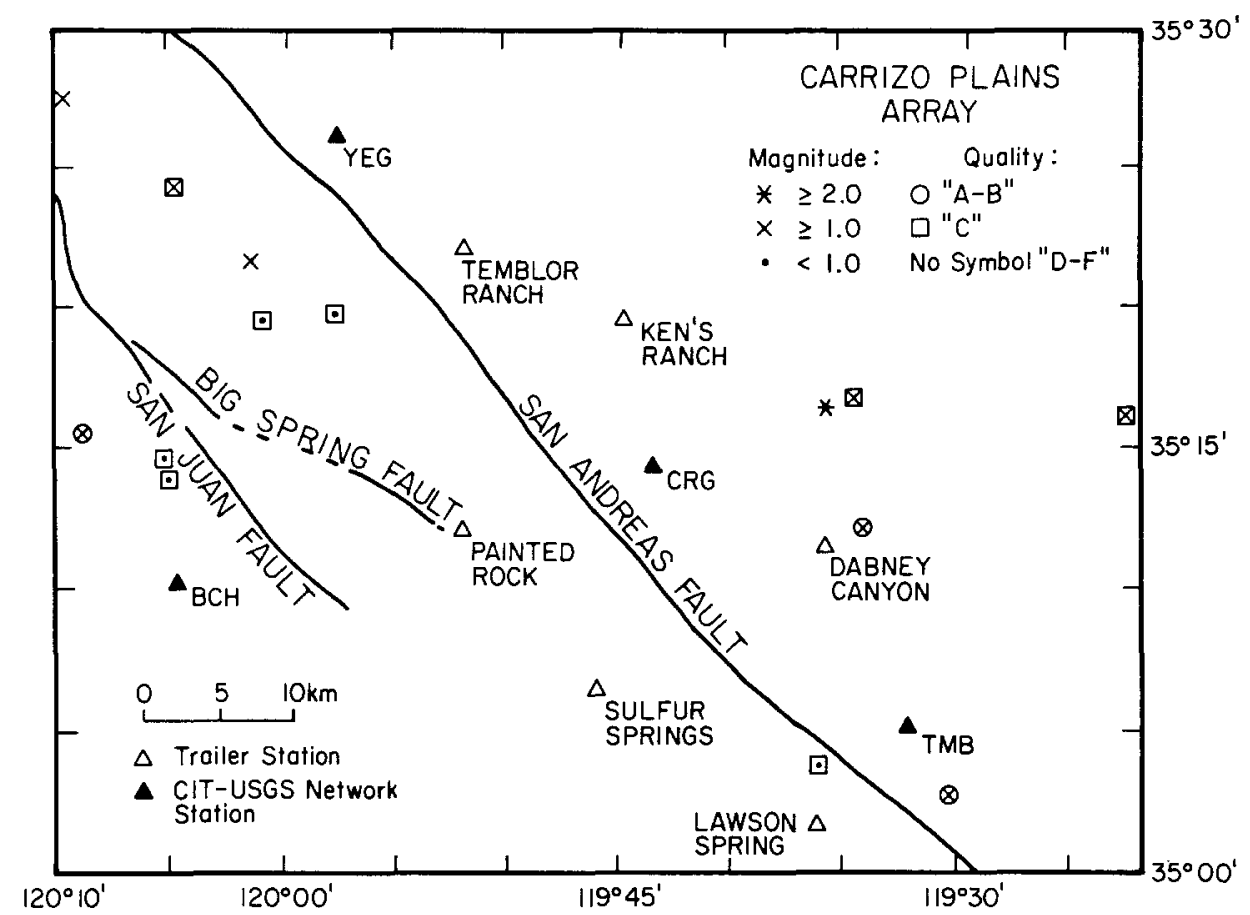

FIG. 2. Map of Carrizo Plains site showing epicenters of located events, major faults, and station locations.

\section{Summary of ObSERVATIONS}

Carrizo Plains site. Six seismograph trailers were deployed along the San Andreas fault in the Carrizo Plains from July 30 to October 6, 1976. Four permanent CaltechUSGS network stations were also operating in the vicinity of the trailer array during this time period. Station locations, epicenters of located events, and the major faults in the Carrizo Plains area are illustrated in Figure 2.

Scrutiny of seismograms recorded during the 69-day observation period revealed 16 locatable microearthquakes with $0.4 \leqq M_{L} \leqq 2.0$. In addition, five probable events with $S-P \leqq 3.0 \mathrm{sec}$, were recorded by too few stations for a hypocenter to be determined. This corresponds to a very low activity rate of 0.3 events/day.

During the period of observation, from two to four trailers were operating sufficiently well for usable data to be obtained. Data recorded by the Dabney Canyon and Ken's Ranch stations were generally unusable due to the high noise 
TABLE 1

Trailer Station Data

\begin{tabular}{lcccc}
\hline \multicolumn{1}{c}{ Station } & Latitude & Longitude & $\begin{array}{c}\text { Gain } \\
\text { Setting } \\
\text { (dB) }\end{array}$ & $\begin{array}{c}\text { Usable } \\
\text { Records } \\
\text { (hr) }\end{array}$ \\
\hline Temblor Ranch & $35^{\circ} 22.06^{\prime}$ & $119^{\circ} 51.20^{\prime}$ & -12 & 860 \\
Ken's Ranch & $35^{\circ} 19.75^{\prime}$ & $119^{\circ} 44.84^{\prime}$ & -24 & 360 \\
Dabney Canyon & $35^{\circ} 11.60^{\prime}$ & $119^{\circ} 35.92^{\prime}$ & -24 & 500 \\
Lawson Spring & $35^{\circ} 01.72^{\prime}$ & $119^{\circ} 36.30^{\prime}$ & -6 & 1040 \\
Sulfur Springs & $35^{\circ} 06.45^{\prime}$ & $119^{\circ} 45.91^{\prime}$ & -6 & 1120 \\
Painted Rock & $35^{\circ} 12.14^{\prime}$ & $119^{\circ} 52.07^{\prime}$ & -12 & 1360 \\
JOH & $34^{\circ} 55.78^{\prime}$ & $119^{\circ} 24.78^{\prime}$ & -12 & 520 \\
SAN & $34^{\circ} 57.81^{\prime}$ & $119^{\circ} 17.17^{\prime}$ & -12 & 750 \\
BUR & $34^{\circ} 47.24^{\prime}$ & $119^{\circ} 25.48^{\prime}$ & -6 & 610 \\
LEE & $34^{\circ} 45.37^{\prime}$ & $119^{\circ} 07.88^{\prime}$ & -6 & 940 \\
SAL & $34^{\circ} 55.55^{\prime}$ & $119^{\circ} 04.93^{\prime}$ & -6 & 540 \\
ABE & $34^{\circ} 51.38^{\prime}$ & $119^{\circ} 12.57^{\prime}$ & -6 & 590 \\
LAK & $34^{\circ} 48.93^{\prime}$ & $118^{\circ} 59.40^{\prime}$ & -12 & 660 \\
Oak Flat & $34^{\circ} 43.16^{\prime}$ & $118^{\circ} 36.24^{\prime}$ & -1.8 & 620 \\
Hauser & $34^{\circ} 42.24^{\prime}$ & $118^{\circ} 31.50^{\prime}$ & -6 & 470 \\
Juday & $34^{\circ} 40.57^{\prime}$ & $118^{\circ} 26.09^{\prime}$ & -12 & 560 \\
San Francisco & $34^{\circ} 37.39^{\prime}$ & $118^{\circ} 21.39^{\prime}$ & -18 & 420 \\
Bee & $34^{\circ} 34.27^{\prime}$ & $118^{\circ} 27.12^{\prime}$ & -12 & 500 \\
Sawtooth & $34^{\circ} 38.90^{\prime}$ & $118^{\circ} 33.72^{\prime}$ & -12 & 300 \\
Munz & $34^{\circ} 44.69^{\prime}$ & $118^{\circ} 22.18^{\prime}$ & -12 & 340 \\
\hline
\end{tabular}

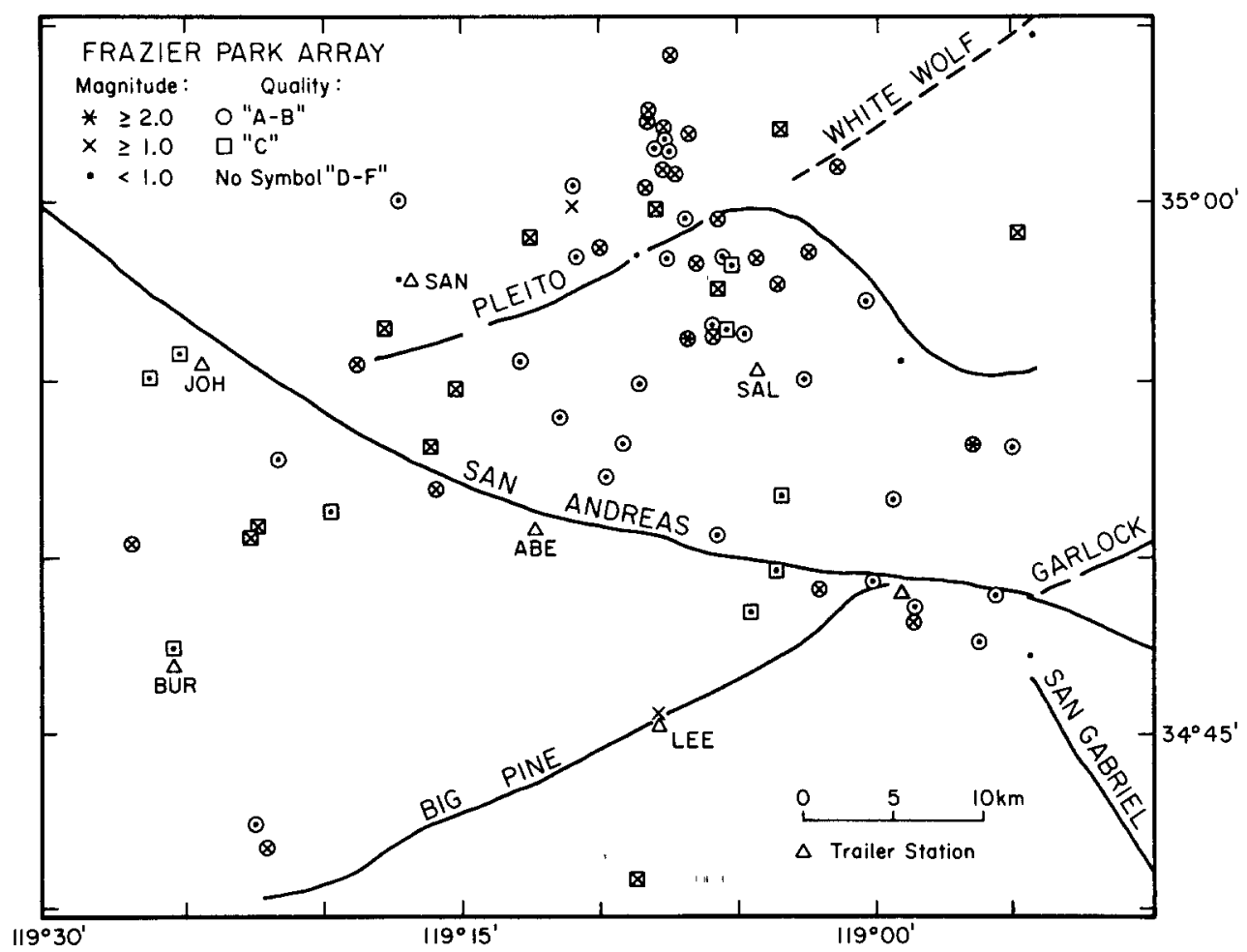

Fig. 3. Map of Frazier Park site showing epicenters of located events, major faults, and station locations. 
levels at these sites. The magnification at the Temblor Ranch and Painted Rock stations was $2.3 \times 10^{7}$. The magnification was $4.5 \times 10^{7}$ at Sulfur Springs and Lawson Spring making them the most sensitive stations.

The epicenter map (Figure 2) indicates that from two to seven of the located events may be directly associated with the San Andreas depending on whether or not the events which are aligned to the northwest between the San Andreas and San Juan faults are considered to be systematically offset from the surface trace of the San Andreas. The uncertainties in the locations of these events make it impossible to correlate them with a particular surface fault trace. The three events slightly to the southwest of the San Juan fault may be due to active seismic processes on that fault. The San Juan fault has been active since the beginning of the Quaternary period, but there is no record of surface displacement in historic times (Jennings, 1975). The three events north of the Dabney Canyon station are not correlatable to any known surface fault trace.

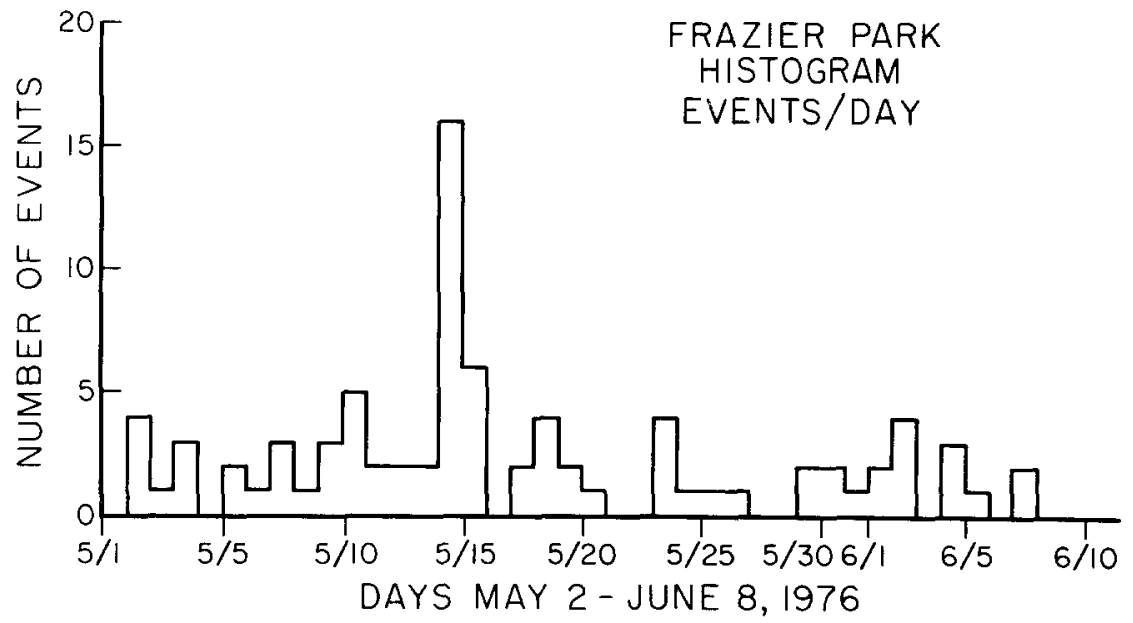

FIG. 4. Histogram of the number of located events at the Frazier Park site versus days. This figure indicates the temporal distribution of seismic activity for the time period the trailers were deployed in the region.

Frazier Park site. Seven trailers were deployed along the San Andreas fault west of Frazier Park, California from April 28 to June 17, 1976. A complete record of microearthquake activity was obtained for the period from May 2 to June 8. During this time period, 84 microearthquakes were recorded by a sufficient number of stations for a hypocenter to be computed. In addition, approximately 30 events with $S-P \leqq 3.0 \mathrm{sec}$ were recorded by an insufficient number of stations for a reliable hypocenter to be determined. The activity rate at this site is 3.0 events/day. Focal depths for most events fall within the range from 4 to $15 \mathrm{~km}$, although many of the computed focal depths are not well constrained. The estimated magnitudes of the events ranged from $M_{L}=-0.1$ to 2.2 . Figures 3, 4, and 5 summarize the data obtained at the Frazier Park site.

The distribution of epicenters indicates that 15 to 20 per cent of the seismic activity may be associated with the San Andreas fault. About 50 per cent of these events occur near the Frazier Mt. intersection of the Garlock, Big Pine, San Gabriel, and San Andreas faults. This suggests the possibility of a localized stress concentration at this tectonically complex site. The temporal distribution of events along the San Andreas appears random. 
The majority of the events located during this observation period were to the north of the trailer seismograph array resulting in an azimuthal gap of $180^{\circ}$ in station coverage for these events. However, most hypocenters are constrained by $S$ $P$ times. The activity in the northern portion of the Frazier Park site is disseminated to the northwest and south of the Pleito fault. The Pleito is a south-dipping reverse or thrust fault, but the exact parameters of its fault-plane orientation and its extent are unknown. The activity near the Pleito can be divided into two groups of events. Almost all the events clustered northwest of the bend in the Pleito occurred in a
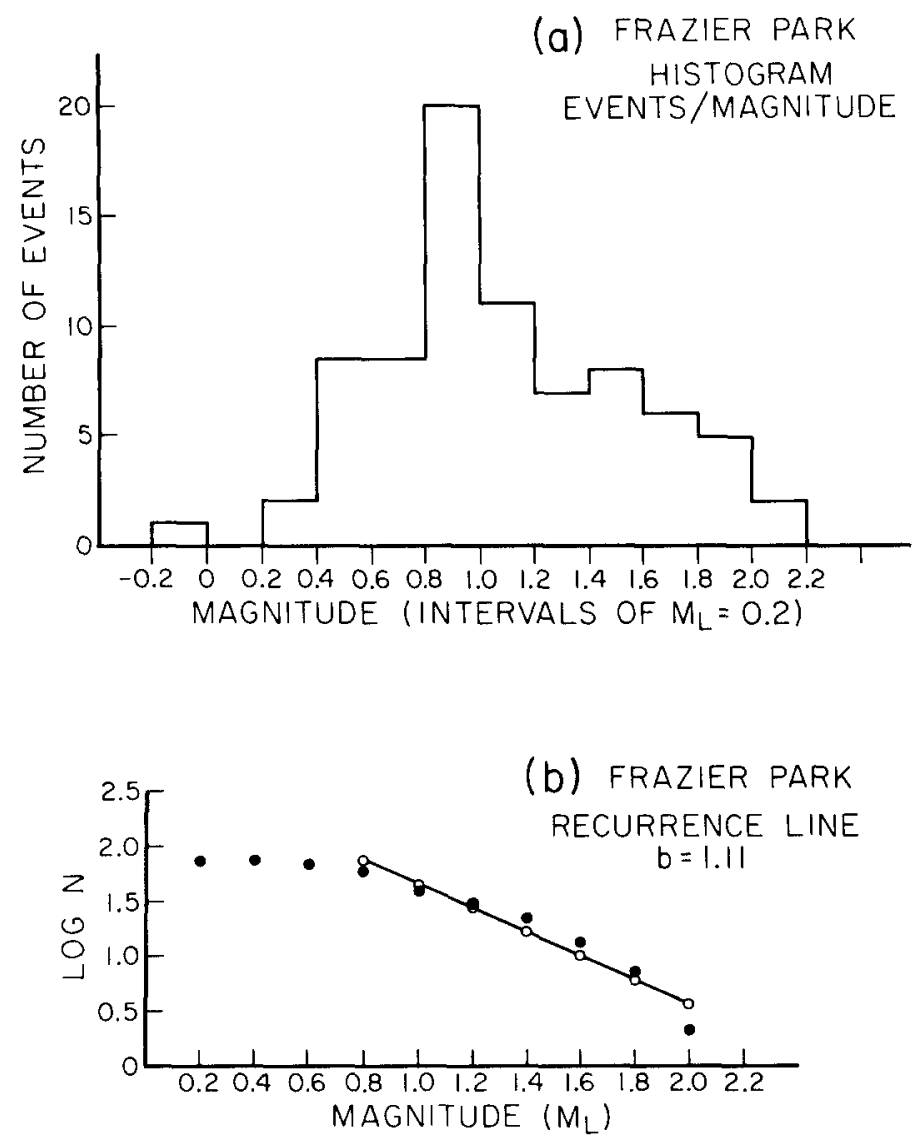

FiG. 5. (a) Histogram of the number of events observed at the Frazier Park site versus magnitude in intervals of 0.2 magnitude units. (b) Plot of $\log N$, where $N$ is the cumulative number of events above a given magnitude, versus magnitude. Circles indicate the points on the line which fits the data best in a least-squares sense.

swarm on May 15. The duration of the swarm was approximately $2 \mathrm{hr}$. Figure 4, which displays an events per day histogram for the Frazier Park site, demonstrates the activity on May 15 is very distinct from the average daily activity. The events along and to the south of the surface trace of the Pleito are more evenly distributed in space and time. These microearthquakes may be associated with the Pleito fault and/or deformation of its fault blocks.

During the time period of these observations, microearthquake activity along the Big Pine fault was nonexistent. The short segments of the Garlock and San Gabriel faults which lie within the study area also appear to be quiescent. The White Wolf 
fault, site of the 1952 Kern County earthquake, trends northeast from the Pleito fault and lies at the boundary of trailer array detection and location capability for the small events of interest. With this limitation noted, it appears that activity along this segment of the White Wolf fault is low.

Figure $5 \mathrm{a}$ is a histogram of the number of events with 0.2 magnitude intervals plotted versus magnitude using the data obtained for the Frazier Park site. The

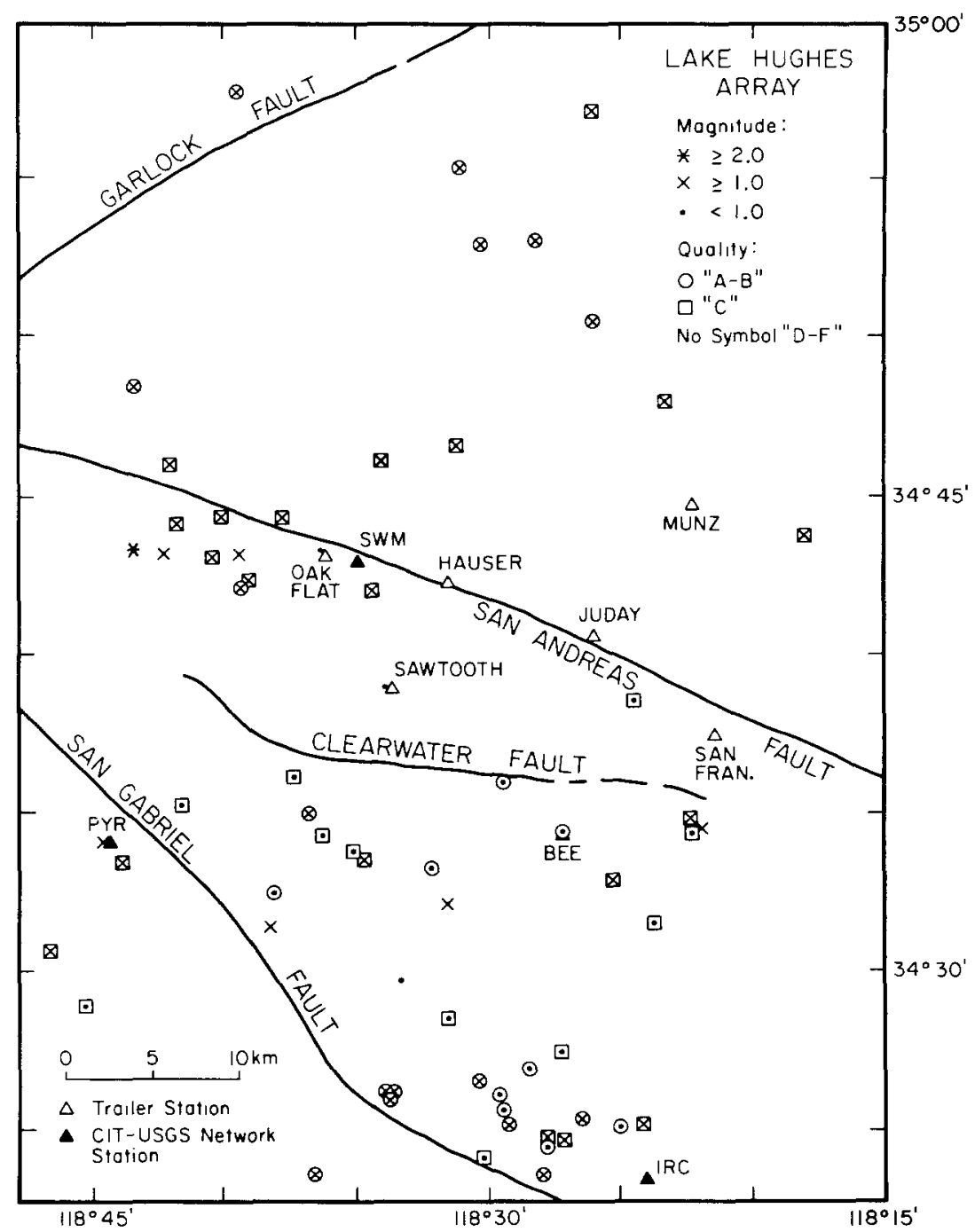

FIG. 6. Map of the Lake Hughes site showing the epicenters of located events, major faults, and station locations.

figure suggests the data set is complete for all events with $M_{L} \geqq 0.8$ to 1.0 . The data for all events with $M_{L} \geqq 0.8$ were fitted to the cumulative recurrence relation, $\log N$ $=a-b M$, using the method of least-squares (Figure 5b). A $b$-value of 1.11 is obtained.

Lake Hughes site. An array of seven trailers was deployed along the San Andreas fault near Lake Hughes, California from February 18 to March 26, 1976. Sixty-five events with estimated magnitudes ranging from $M_{L}=0.4$ to 2.0 were located using 
the seismograms recorded during this time period. Seven other events with $S-P \leqq$ $3.0 \mathrm{sec}$ were recorded, but not locatable. The activity rate at the Lake Hughes site was 1.9 events/day. Three permanent Caltech-USGS network stations were operating near the Lake Hughes site while the trailer array was operating. Records of events recorded at these stations were used to enlarge the areal coverage of the trailer station array. Station locations, epicenters of located events, and major faults are shown in Figure 6.

The distribution of epicenters indicates that about 25 per cent of the total activity

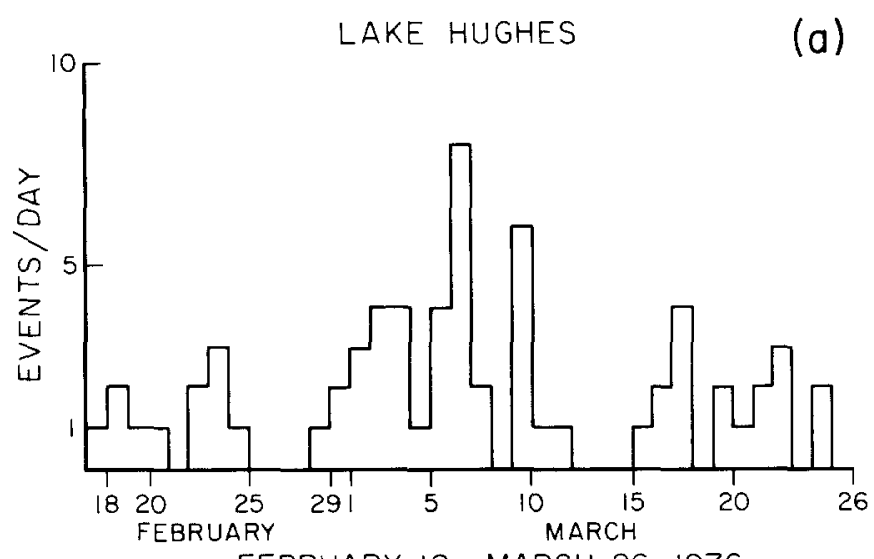

FEBRUARY 18 - MARCH 26, 1976

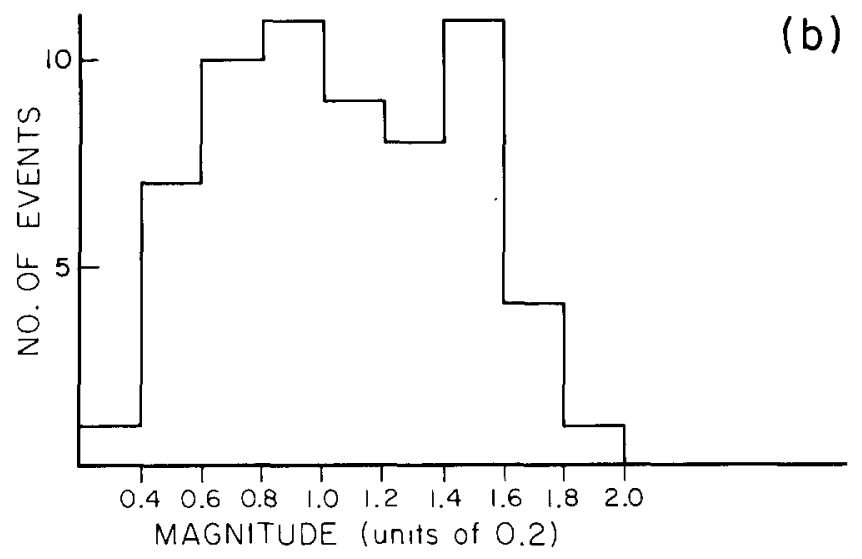

FIG. 7. (a) Histogram of the number of located events for each day the Lake Hughes array was operating. (b) Histogram of the number of events within 0.2 magnitude intervals plotted versus magnitude using the Lake Hughes data.

observed in the Lake Hughes area may be directly associated with the San Andreas fault. Almost all the activity along the San Andreas occurs slightly to the west of stations at Oak Flat and SWM. There is a region of uniformly distributed microearthquake activity between the Clearwater and San Gabriel faults. Both of these faults show evidence of activity during the Quaternary period, but no surface displacement has occurred along these faults in historic times (Jennings, 1975). About 50 per cent of the events in the area bounded by the Clearwater and San Gabriel faults have estimated magnitudes less than 1.0. A dense cluster of epicenters is located about 8 $\mathrm{km}$ northwest of station IRC, just north of the surface trace of the San Gabriel 
fault. The epicenter of the 1971 San Fernando earthquake is located approximately $20 \mathrm{~km}$ to the southeast of IRC. The proximity of the southern portion of the Lake Hughes site to the epicentral region of the San Fernando earthquake is one possible explanation of the high rate of activity in this region. The temporal distribution of microearthquake activity observed in the Lake Hughes area during this study period is displayed in Figure 7a. The peak in activity which occurs between March 7 to 10 is relatively well distributed spatially. About one-third of the events with origin times within this time period are located within the cluster of events northwest of IRC.

A histogram of the number of events plotted versus 0.2 magnitude intervals is shown in Figure $7 \mathrm{~b}$. This figure suggests the data set is complete for events with $M_{L}$ $\geqq 0.8$, although there is an anomalous number of events with $1.6 \geqq M_{L} \geqq 1.4$.

\section{Comparison With Other Microearthquake Surveys}

Brune and Allen (1967) conducted a microearthquake survey at the same sites occupied by this survey using the same instrumentation. The total usable recording time they reported at each of the three sites was 4.5 days at Carrizo Plains, 1.5 days at Frazier Park, and 152 days at the Lake Hughes site. The activity rates observed during these time periods were 0.0 events/day at the Carrizo Plains, 2 events/day at Frazier Park, and 0.1 event/day at Lake Hughes. In comparison with the activity rates observed during the time periods discussed in this report, activity rates for the Carrizo Plains and Frazier Park areas are about the same as the rates observed in the 1965 to 1966 Brune and Allen study. The activity rate at the Lake Hughes site has increased by more than an order of magnitude.

A reconnaisance survey of microearthquake activity at the Carrizo Plains site made by Caltech in 1975 resulted in three locatable events, $M_{L}>1.0$, in a 2.5-day observation period. In addition, 10 small events were recorded by more than two stations. This activity rate is much higher than the rate observed in this survey or by Brune and Allen (1967). However, the period of observation was too short for this result to be considered representative of the seismic activity in this area.

\section{CONCLUSION}

Close scrutiny of seismograms recorded by an array of trailer seismograph stations situated at three different sites along the northern half of the "Big Bend" in the San Andreas fault indicates seismic activity rates of 0.3 events/day in the Carrizo Plains, 3.0 events/day near Frazier Park, California, and 1.9 events/day near Lake Hughes, California. The rates observed in the Carrizo Plains and Frazier Park areas are about the same as rates observed in a survey by Brune and Allen (1967). The activity level measured near Lake Hughes during a 38-day observation period is more than an order of magnitude higher than the activity rate reported by Brune and Allen for a 152-day observation period. The significance of this long-term temporal variation in activity levels at the microearthquake threshold is presently unknown. However, a number of recent studies (Inouye, 1965; Kelleher and Savino, 1975; McNally, 1976; Ohtake, 1976; Sekiya, 1976; Engdahl and Kisslinger, 1977; Fuis and Lindh, 1977; Ishida and Kanamori, 1977; Lindh et al., 1977) indicate that the long-term seismicity pattern is one of the key data for understanding the mode of stress build-up before large earthquakes. In light of the observed long-term temporal variation in seismic activity at Lake Hughes, it is important to continue routine 
monitoring of seismic activity at the microearthquake threshold and to systematically study temporal and spatial variations in seismicity.

\section{ACKNOWLEDGMENTS}

This research was supported by U.S. Geological Survey Contracts 14-08-0001-15893 and 14-08-000116711. R. Carlson was supported by a Beno Gutenberg Fellowship and a National Science Foundation Graduate Fellowship. We especially thank Carl Johnson for generating the Southern California seismicity map (Figure 2), and D. Tanner, L. Blayney, and F. Lehner for technical support.

\section{REFERENCES}

Brune, J. N. and C. R. Allen (1967). A microearthquake survey of the San Andreas Fault system in southern California, Bull. Seism. Soc. Am. 57, 277-296.

Engdahl, E. R. and C. Kisslinger (1977). Phenomena precursory to a magnitude 5 earthquake in the central Aleutian Islands (abstract), EOS 58, 433.

Fuis, G. and A. Lindh (1977). A change in fault-plane orientation between foreshocks and aftershocks of the Galway Lake earthquake, $M_{L}=5.2,1975$, Mojave desert, California (submitted for publication).

Hileman, J. A., C. R. Allen, and J. M. Nordquist (1973). Seismicity of the Southern California Region 1 January 1932 to 31 December 1972, Seismological Laboratory, California Institute of Technology.

Inouye, W. (1965). On the seismicity in the epicentral region and its neighborhood before the Niigata earthquake, Kenshin Jiho 29, 139-144 (in Japanese).

Ishida, M. and H. Kanamori (1977). The spatio-temporal variation of seismicity before the 1971 San Fernando earthquake, California, Geophys. Res. Letters 4, 345-346.

Jennings, C. W. (1975). Fault Map of California, California Division of Mines and Geology.

Kanamori, H. and D. Hadley (1975). Crustal structure and temporal velocity change in southern California, Pageoph 113.

Kelleher, J. and J. Savino (1975). Distribution of seismicity before large strike-slip and thrust-type earthquakes, J. Geophys. Res. 80, 260-271.

Lee, W. H. K., R. E. Bennett, and K. L. Meagher (1972). A method of estimating magnitude of local earthquakes from signal duration, U.S. Geol. Surv. Open File Rept. 1972.

Lee, W. H. K. and J. C. Lahr (1975). HYPO 71 (revised): A computer program for determining hypocenter, magnitude and first motion pattern of local earthquakes, U.S. Geol. Surv. Open File Rept. 75-311.

Lehner, F. E. and F. Press (1966). A mobile seismograph array, Bull. Seism. Soc. Am. 56, 4, 889-897.

Lindh, A., G. Fuis, and G. Mantis (1977). Foreshock amplitudes and fault plane changes: An earthquake precursor? (submitted for publication).

McNally, K. (1976). Spatial and temporal and mechanistic character in earthquake occurrence, Ph.D. Dissertation, University of California, Berkeley, $140 \mathrm{pp}$.

Ohtake, M. (1976). Search for precursors of the 1974 Izu-Hanto-Oki earthquake, Japan, Pure Appl. Geophys. 114, 1083-1093.

Sekiya, H. (1976). The seismicity preceding earthquakes and its significance to earthquake prediction, Zisin 29, 299-311 (in Japanese).

Sieh, K. E. (1978). Prehistoric large earthquakes produced by slip on the San Andreas fault at Pallett creek, California, J. Geophys. Res. 83, 3907-3939.

\section{SEISMOLOGICAL LABORATORY}

California Institute of Technology

Pasadena, California 91125

CONTRIBUtion No. 3105

Manuscript received June 9, 1978 